\title{
DEMOCRACY, LEADERSHIP AND NATION BUILDING IN NIGERIA
}

\author{
Charles Chukwuemeka Nweke* \\ http://dx.doi.org/10.4314/og.v11i 1.8
}

\begin{abstract}
Anchored on socio-political principles like freedom, human rights and rule of law, democracy is deemed the best form of government. Given its appealing prospects, democracy has become evidently prevalent in the contemporary world's governance. Thus, nations operating other forms of government have over time either strongly sought democracy or are compelled to do so by external forces. Dissatisfied with a long-term period of military rule, Nigerians clamored for democratic rule and the nation has since 1999 witnessed civilian transitions of power within democracy. For Nigerians, the beauty of their hard earned democracy lies in its proclivity towards integral and sustainable national development. The thrust of democracy anywhere is determined hugely by the manner and style of leadership by which the system of government is run. Any democracy driven by bad leadership not only stunts nation building but engenders expedition for political alternatives. From a philosophical stance, this paper critically examines Nigerian democracy and identifies corruption as a major leadership problem bedeviling Nigerian nation building. It proposes attitudinal-changebased orientation of leadership for service as more dignifying and rewarding which in turn enhances progressive and sustainable development of Nigeria and indeed Africa.
\end{abstract}

\section{Introduction}

The birth of any commonwealth or body politic is usually preceded by visible expressions of dissatisfaction for a society approximating that of a state of nature. Being an abode of no law and perpetual war, consequent upon man's natural ego-centric inclinations, the state of nature lacks mechanisms for common good and societal 
preservation. Thomas Hobbes, John Locke and Jean Jacques Rousseau are popular social contract theorists who conceptualized political institutions to entail organic transition from the precarious state of nature to civil society. Whereas Hobbes conceived of an unappealing commonwealth of absolute monarchy, Locke thought that the natural rights to life, liberty and property are to be best preserved in a democratic system of government. Prior to the era of modern philosophy, theories of democracy were manifest in the ancient Greek political thoughts "....as rule by the citizens in general (nevertheless excluding women and of course slaves) in contrast to government by the rich and aristocratic." (Oxford Dictionary of Philosophy, 2005). In the Republic Book VI, Plato graded democracy below oligarchy, monarchy and aristocracy for lacking the enterprise and expertise for adequate governance of society. He was apprehensive that, in a democratic rule, those who are expert at winning elections and nothing else will eventually dominate democratic politics. Aristotle considered democracy (rule by the people) the most moderate form of government besides monarchy and oligarchy. Whereas monarchy remains the tyrannical instruments of kingship, oligarchy is a form of aristocracy favouring mainly the rich, but democracy is the rule to the advantage of the poor. In Book IV, Chapter four of his Politics, Aristotle enunciated forms of democracy. In his words:

There are several kinds of democracy. The first sort is based particularly on equality, where the poor and the well-off are treated equally and the majority rule since both groups have equal authority to rule. Other kinds of democracy include having the rule of law but allowing all to take part in offices, or allowing the multitude and not the law to have authority. In such a case, "the people become a monarch, from many combining into one." Properly speaking, however, such an arrangement is not really a 
regime, because "where the laws do not rule there is no regime."

The contemporary popularity of democracy with much emphasis on rule of law, freedom and rights tends to have evolved from the Lockean social contract thesis with its stipulations of the prevalent democratic arms of government- the executive, legislative and judicial. Considered as a mainly constitutional driven system of government, Locke vested much of democratic importance to the legislature in view of its participatory role. Given its participatory and liberating tenets together with its developmental prospects, democracy has its Lincolnian definition as government of the people, by the people and for the people and adjudged the best form of government. Zakka (2014) puts it that:

Throughout history, the most important aspects of the democratic way of life have been the principles of individual equally and freedom. Accordingly, therefore, citizens in a democracy should be entitled to equal protection of their persons, possessions, and rights; have equal opportunity to pursue their lives and careers; and have equal rights of political participation. In addition, the people should enjoy freedom from undue interference and domination fry government. They should be free, within the framework of the law, to believe, behave, and express themselves as they should as they wish. Democratic societies seek to guarantee their citizens certain freedom, including freedom of religion, freedom of the press, and freedom of speech. Ideally, citizens also should be guaranteed freedom of association and assembly, freedom from arbitrary arrest and imprisonment, and the freedom to work and live where and how they choose. 
In practice, many nation of the globe including Nigeria have embraced democratic rule in replacement of loathsome military regimes.

\section{Leadership within Nigerian Democracy}

The various definitions of leadership revolve around the ability to organize individuals for the achievement of a common goal. The trait theory of leadership, which projects the idea that leadership is based on individual attributes, was prevalent in the earlier scholarly period as a seeming response to Plato's quiz of the constituent quality of a leader. Unable to subsist the attendant 'leaders are born' versus 'leaders are made' debate, the trait theory is, over the era, competed with alternate theories. Prominent scheme of the post-trait theories is to present vigorously a situational leadership philosophy. Leadership roles and dispositions vary with given situations. Leadership variation is as natural as existential situations and leaders, whether substantial or developed, are situational emergentists.

Certain existential circumstances turn out concomitant leadership features. Within the political setting, leadership tends to strongly equate ruler ship. Any political setting guided by laws presupposes ruler ship. Hence various systems of government embody appropriate ruler.

In his article, "Leadership Philosophies", Kimberly Pendergrass (2013) adumbrated nine leadership traits one of which is the democratic (participatory) leadership philosophy. He maintained that:

A leader who practices this leadership philosophy offers guidance to organization members while still being a part of the group. This type of leadership is democratic, considerate, participative, and consultative. It focuses on creating and maintaining good working relationships that are supportive and interactive. Followers are encouraged to participate and engage with the decision making process and 
their input is considered. This results in the group being more motivated and creative as a whole.

This kind of leadership is supposedly the vision of Locke, Rousseau and Mill's theories of democracy. Leadership in the democratic system of government remains the exercise of political powers within the frame of constitutional provisions duly legislated for common good. Such leadership approximates Brad Smith's (2014) view in his article "Personal Leadership Philosophy" thus:

Your title makes you a manager; your people will decide if you are a leader. Leadership is not the job of putting greatness into people, but rather the recognition that greatness already exists. The role of a leader is to provide the grand challenge, create the environment and invest in the individual to inspire that greatness to emerge. Leadership is about inspiring a group of individuals to achieve extraordinary things.

For him, the qualities of a good leader include:

Integrity: I am a principles-based leader, and will always say what I mean, and mean what I say. In the end, my words and my actions should be synonymous. Humility: Mankind has many gifts, and I do not view myself as one of them. I seek to learn from others, treat every success and failure as a learning opportunity, and strive to be a better version of myself each and every day. Teamwork: I believe that a player that makes the team great is far more valuable than simply a great player. A team plays for a cause greater than itself or any individual, and believes that only together can we create outcomes that will echo an eternity. 
The Federal Republic of Nigeria's embrace of democracy in 1999 saw the transition of political power from the grip of the military to civilian rule. The country adopted a model of democracy that is basically representative with three tiers and arms of government. Thus the exercise of political power resides mainly within the confines of three arms of government viz; the executive, the legislature and the judiciary both at the federal, states and local governments. At the federal level, Nigeria runs a bicameral legislature of the Senate and House of Representatives. The Senate is constituted of 109 members, three of which are elected from each of the thirty-six existing States of the Federation. The House of Representatives have 360 seats drawn from federal constituencies across the country. Leadership within Nigerian democracy as in every other democracy is either by election or executive appointment. Hence, seekers of political offices either contest election or lobby for appointments.

From the inception of the Nigerian democratic dispensation of the fourth republic headed by OlusegunObasanjo, to the present, Nigerian political leadership has witnessed three civilian to civilian transitions. Of course, the constitution of the Federal Republic of Nigeria stipulated leadership tenures for mainly key political leadership positions occupied through elections. After the general election of 2007, Obasanjo handed over power to Late Umar Musa Yar' Adua whose administration was short-circuited by his demise in 2009. The 2011 general election propped up Jonathan Goodluck, who was vice president in Yar'Adua's time but sworn-in as president and completed that tenure.

Despite the laudability of current sustenance of democracy in Nigeria, the question remains as to the extent Nigerian democratic leaders have justified the essence of democratic leadership. If Nigerians' clamour for democracy was propelled by the quest for good governance aimed ultimately at enhanced national development, then Nigerians must have clamoured for the assurances of the general benefits of democracy. This definitely includes visions for real democratic governance. It simply entails 
that Nigerian democratic leaders must be disposed to lead the citizenry on the parts of rule of law, protection of human rights and freedom, enhanced public participation as well as integral and sustainable development. So far, the benefits of democratic governance are evident in Nigeria. The current rating of Nigeria as Africa's greatest economy is owed to democracy. A relative advancement in Nigerian politics rests in the actuality of successful civilian to civilian transitions within fifteen years of uninterrupted democracy. On the minimum, Nigerians could presently boast of quasi satisfaction as regards, the replacement of civility of governance against the preceding military dictatorship. Aside these and more, some leadership challenges within the democratic setting are discernible.

\section{Leadership Challenges of Nigeria Democracy}

Military-in-Civilian Garb Leadership: The 1999 democratic military-to-civilian transition saw the emergence of retired army General Olusegun Obasanjo as the first fourth republic Nigerian President. That administration was fraught with a subtle militarization of a civilian government. This view is corroborated by Akuta's (2009) submission that:

Sincerely speaking, the only gain we have got in the past 10 years of democracy in Nigeria is simply that we have had a civilian regime. Besides it has not been truly civilian in the true sense of it. 8 years out of the last 10 years (Obasanjo's administration) was a quasi-military government because Obasanjo ruled Nigeria like a military head of state.

Obasanjo's military approach to democratic rule popularized presidential arbitrary imposition of elective candidates with sheer impunity, a situation from which the citizenry developed the slogan 'selection' in place of election. The Odi military massacre of November 20, 1999 remains one of the most undemocratic and 
ignoble actions of that administration. The military-styled democratic rule of the government which was nothing much short of despotism and dictatorship institutionalized the cankerworm of Nigerian democratic leadership- corruption.

\section{Public Sector Corruption}

In Nigeria, corruption is not a term specific to the nation's democracy but a reality rooted and developed within the military era. However, "in philosophical, theological, or moral discussions, corruption is spiritual or moralimpurity or deviation from an ideal." (Wikipedia) Defined by Transparency International as “... the use of entrusted power for private gain", corruption in any political setting represents gross betrayal of public trust. Nigeria's notoriety for Advanced Fee Fraud popularized as 419 together with the spate of economic and financial crimes germinated and sprouted within the military regimes of Ibrahim Babangida and SaniAbacha. Ranging from treasury looting and embezzlement of public fund to money laundering, abuse of power, bribery, the leadership of these administrations thrived on so much corruption. Hence, researched revelations about them could be gleaned from Wiki account thus:

The regime of General Ibrahim Babangida is seen as the body that legalized corruption. His administration refused to give account of the Gulf War windfall, which is estimated to be $\$ 12.4$ billion. He annulled a democratic election in Nigeria on June 12, 1993 and decided to instate Ernest Shonekan as his successor in August 27, 1993 when he stepped down as head of the military regime. However, within 3 months of the handover, General Sani Abacha seized control of the government while Babangida was on a visit to Egypt. He lives in a very exquisite mansion in his home state (Nigerstate) in the Northern part of the country... The death of the general Sani Abacha revealed the global 
nature of graft. French investigations of bribes paid to government officials to ease the award of a gas plant construction in Nigeria revealed the global level of official graft in the country. The investigations led to the freezing of accounts containing about $\$ 100$ million United States dollars. In 2000, two years after his death, a Swiss banking commission report indicted Swiss banks for failing to follow compliance process in allowing family and friends of Abacha access to accounts and depositing amounts totaling $\$ 600$ million US dollars into the accounts. The same year, a total of more than $\$ 1$ billion US dollars were found in various accounts throughout Europe.

Nigerians clamour for democracy during the protracted military rule became an expression of the people's desire for political positive change. Most unfortunately, the corrupt leadership inherited from military rules equally permeated the democratic era. Apart from economic and financial corruption, political corruption ranks very high with the greatest feature of electoral malpractices.

Being one of the greatest oil producing nations of the globe, Nigeria is economically wealthy with prosperous oil explorations and businesses. The nation's economic resource is controlled by the Federal government which makes monthly allocations to both State and local governments with a stipulated sharing formula. The control and distribution of the wealth of the nation is constitutionally placed in the hands of both elective and political appointive leaders. Despite the level of Nigeria's economic wealth, majority of its citizenry are living below poverty level. Global Development Index (GDI) continually place Nigeria at the baseline of global development. The reason remains that instead of ensuring adequate wealth distribution and national development, Nigeria's riches are confined to the coffers of few corrupt leaders. To inflate the situation, Nigeria's political offices are so constitutionally empowered in some cases 
with the immunity clause that protect certain office holders from public prosecution. With frail checks and balances and given the wide access to national wealth provided through the acquisition of political power, political offices become unduly attractive. Thus, such offices become gravely competitive as many individuals consider it avenue to gain access to the national cake.

The Marxist theory of dialectical materialism in which the economic structure is the propeller of other structures plays out strongly in Nigeria democracy. The motivating factor of craze for political office is no more than self-interest of economic empowerment at the expense of common good and national development. The unfortunate situation is that those who do not possess leadership capacity seek leadership positions and often acquire power either by hook or crook. In praxis, most Nigerian democratic leaders are oblivious of either the workings of governance or the principles of democracy. The result is that Nigerian democratic setting has become a terrain of more visionless and purposeless leaders without integrity. Most unfortunately, the institutions designated with the duties of protection of democratic ideals are degraded into mechanisms for achieving corrupt objectives. The June 2003 final report of Nigeria Survey and Corruption Survey Study, Institute for Development Research, Ahmadu Bello University, Zaria (IDR, ABU Zaria), provides a practical insight into the reality of Nigeria institutional corruption.

\section{Rating Institutions}

1. Nigerian Police

2. Political Parties

3. National and State Assemblies

4. Local and Municipal Governments

5. Federal and State Executive Councils

6. Traffic Police and Federal Road Safety Corps

7. Power Holding Company of Nigeria 
One of the greatest manifestations of corruption in Nigerian democratic leadership is the inability to ensconce a free and fair election. Even the judiciary considered the last hope of the common man is equally enmeshed in collaborative corruption with the political bigwigs. Thus it is possible within Nigerian democracy for political moneybags to influence judicial decisions in order to install cohorts in power.

\section{Ethnicity and Religion}

It may not be so much out of place to hold that the 1914 Lugardian amalgamation of Northern and Southern protectorate to produce the present Nigerian State was the genesis of Nigeria's ethnic rift. If the formation of a nation-state should be the product of a social contract, the most feasible States must be the ones founded on commonality. Common origin ensures the 'we' feeling to impel a nation on the path of common purpose. Stable sovereignties are anchored on homogeneity and natural sense of indigenship. Without prejudice to certain multi-cultural polities, a heterogeneous sovereignty administers its affairs with much exertion, since it struggles with the management of expanded diversity, irrespective of its presumed harmony.

A country of over two hundred ethnic nationalities coalesced into three major tribe (Yoruba, Hausa and Igbo) with two major religions (Christianity and Islam), Nigerian governance, from the point of colonial independence, has been a display of ethnic/religious politics. Within the current democratic setting, ethno-religious politics entrench strong leadership tussle between the North (Muslims) and South (mainly Christians) giving rise to series of ethno-religious crises resulting in religious bigotry, bornto-rule orientation, incessant killings and wanton destruction of property, insurgency and terrorism. The Yar'Adua administration bore the stings of Niger Delta militancy guised as ethnic struggle for emancipation from political cum developmental marginalization. After the 2011 general election that threw up Jonathan Goodluck as President from the region of Southern 
minority, the nation witnessed wide post-election violence in the North where comments of making the tenure ungovernable for the President preceded the current virulent Boko Haram insurgency.

The sub-division of Nigeria into six geo-political zones and introduction of federal character are measures put in place for ethnic harmony in the polity. Hence, the distribution of democratic leadership is widely guided by zoning formula at various levels. Aside the ruling People's Democratic Party (PDP) which is vividly an umbrella party reflecting some level of national unity, the formation of most other political parties are motivated by ethnoreligious factors.

\section{Good Leadership as a Parameter for Nigeria Nation Building: The Role of Philosophy}

Being essentially the critical enquiry into reality, philosophy basically beams its rational searchlight on any discipline, concept, idea, postulations in order to correct their adequacies. In philosophy lies the origin of socio-political theories and consequently foundational about the thesis of leadership. The preceding section showcases a concise espousal of forms of government in the works of Plato and Aristotle. If democracy is deemed the best form of government consequent upon its people oriented prospects, leadership within democracy ought to reflect the will of the people. In simple terms, leadership of any democracy should basically be for service. Of course service could be double-dimensional. There is apparent difference between objective service and self-service. Leadership of self-service approximates the attitudes of corrupt leaders who utilize the privileged positions of leadership for personal aggrandizement. This is the kind exhibited by many corrupt Nigerian democratic leaders a situation that results in developmental retardation of the nation.

Leadership of objective service refers to purposeful leadership aimed basically at the common good. Such leadership is most appropriate for democratic governance. For such kind to be feasible in Nigeria democracy, philosophy would prescribe 
adequate capacity building for prospective leaders. The designers of the 1999 Nigerian constitution which the current democracy operates, makes openness for people of low education to vie for political offices. As such, it invariably provides for even touts to occupy positions of leadership. The Nigerian constitution ought to be amended to make stipulations for quality leadership. What kind of law would an illiterate legislator make? Nigerian parliament is filled with many half educated, less effervescent and nominal legislators who only grace the seats of the hallowed chambers, collect their entitlements without any meaningful legislative contributions. Many of them are simply ignorant of the principles of democracy, let alone legislative business. Some others are just aloof because their interests are far from legislation. Although Plato did not subscribe for democracy, he placed high intellectual capacity as the greatest parameter for quality leadership which of course is found within the class of philosophers. Hence, unless philosophers become kings, the society cannot progress developmentally. Plato philosopher king postulation signifies the import of critical thinking as a requisite for quality leadership even in a democratic setting.

The over concentration of political decisions at the centre necessitates quest for devolution of power and fiscal federalism. Nigerian democratic leaders ought to be driven by the visions of common good without ethno-religious favoritism. The establishment of some institutions like Nigerian Institute of Peace and Strategic Studies (NIPS) together with other activities designed for leadership capacity building is a commendable attempt. Nevertheless, critical thinking studies, with emphasis on leadership for service, are highly recommended as pre-requisite for any leadership position. Importantly, there ought to be legislation for constant compulsory leadership training for occupants of leadership offices in Nigerian democracy with pragmatic and sustainable policy implementation mechanisms. With these human development indices in place, it could be held that Nigerians can be 
assured of rapid, sustainable and integral development through democratic governance.

\section{Conclusion}

With the critical tool of philosophy, this paper identified corruption and ethno-religious politics as the major problems of leadership in Nigerian polity. Reflection on the nature and various leadership concepts presents leaders as situational emergentists. For a thriving and stable Nigerian democracy, service driven leadership critical thinking orientation is philosophically prescribed.

*Charles Chukwuemeka Nweke PhD, Department of Philosophy, Nnamdi Azikiwe University, Awka

E-mail: Nkesun2002@yahoo.com 


\section{References}

Akuta,

C.V.

(2009),

http://www.newsdiaryonline.com/chinedu_demo.htm, Accessed on $4 / 10 / 2014$

Aristotle, Politics, http://www.gradesaver.com/aristotlespolitics/study-guide/section4/ Accessed on 03/10 2014

Pendergrass, K. (2013), “Leadership Philosophies”, https://www.udemy.com/blog/leadership- philosophy/, Accessed on $10 / 10 / 2014$

Plato, Republic,http://plato.stanford.edu/entries/democracy/ , Accessed on 01/10/2014

Smith, B. (2014), "Leadership Philosophy",

http://www.academyleadership.com/LeadershipPhilosophy/philosop hy001.asp, Accessed on 10/10/2014

Wikipedia, "Corruption in Nigeria", http://en.wikipedia.org/wiki/Corruption_in_Nigeria, Accessed on $6 / 10 / 2014$

Zakka, I. (2014), "Dividend of Democracy in Nigeria: Myth or Reality" http://www.crossnewskaduna.com/church-and-society/64dividends-of-democracy-in-nigeria-a-myth-or-a-reality, Accessed on 3/10/2014 